\title{
THE HEALTH CONDITION OF FEMALE VICTIMS OF VIOLENCE ZDRAVJE ŽENSK, KI DOŽIVLJAJO NASILJE Vesna Leskošek ${ }^{1}$
}

\author{
Prispelo: 9. 10. 2012 - Sprejeto: 7. 1. 2013
}

\begin{abstract}
Introduction: The article addresses one of the most vulnerable social groups - women who have experienced various types of violence. The problem is presented through a discussion of the consequences of violence on women's health. Based on the analysis of the research data, the article proposes measures that should boost health care policies in handling violence against women.

Methods: The source of data is the Survey on Violence Against Women in the private sphere and partnership relations conducted in 2010. The sample consisted of 3000 women, equally stratified by age, type of neighbourhood and region. The research was quantitative and the response rate was $25 \%(n=752)$, which is an average response rate when researching intimate spheres accompanied by fear, shame or emotional distress.

Results: The results have shown that violence has a powerful and lasting effect on health. In some cases, injuries lead to lasting disability. Psychological and mental disorders are also present, including depression, nightmares, fear, shame, anger, the feeling of threat and distrust. The problems are compounded by a distrust of professional help, which further affects their health condition.

Conclusions: health policies should include training and knowledge of the causes, dynamics and consequences of violence, so that women could be encouraged to report violence. The first step was made when the relevant rules of procedures were adopted, but the process must continue with the drawing of protocols, the definition of the responsibility of individual professions within health care and cooperation with other institutions.
\end{abstract}

Key words: women, violence, physical health, mental health, injuries, consequences, measures within health care

Izvirni znanstveni članek UDK 614:364.632

\section{Izvleček}

Uvod: Članek se nanaša na eno najranljivejših družbenih skupin, in sicer na ženske, ki doživljajo različne oblike nasilja. Problem je prikazan z vidika posledic, ki jih ima nasilje na zdravje. Na osnovi analize raziskovalnih podatkov so podani predlogi za krepitev zdravstvenih politik do nasilja nad ženskami.

Metode: Vir podatkov je Nacionalna raziskava o nasilju nad ženskami v zasebni sferi in partnerskih razmerjih iz leta 2010, izvedena na vzorcu 3.000 žensk, enakomerno stratificiranem po starosti, tipu naselja in po regiji. Raziskava je kvantitativna, odzivnost 25-odstotna (n=752), kar je običajna odzivnost pri raziskovanju intimnih področij, ki jih spremlja strah, sram ali duševne stiske.

Rezultati: Ti pokažejo, da ima nasilje močen in dolgotrajen vpliv na zdravje. Poškodbe v nekaterih primerih vodijo $v$ trajno invalidnost. Psihične in duševne težave se pojavljajo kot depresija, nočne more, strah, sram, jeza, občutek ogroženosti, nezaupanje. Težave spremlja nezaupanje $v$ strokovno pomoč, kar ima posledice na slabše zdravje.

Zaključki: Zdravstvene politike morajo vključevati vednost o vzrokih, dinamiki in o posledicah nasilja, da lahko krepijo ženske pri razkrivanju nasilja. Prvi koraki so narejeni s sprejetjem ustreznih pravilnikov, treba pa je nadaljevati izdelavo protokolov, odgovornost posameznih poklicev $v$ zdravstvu in sodelovanje z drugimi ustanovami.

Ključne besede: ženske, nasilje, fizično zdravje, duševno zdravje, poškodbe, posledice, ukrepi na področju zdravstva 


\section{INTRODUCTION}

The prevalence of violence against women and the decision of perpetrators to commit violence depend on the symbolic, social and economic status of women and children in the society and in family. Our understanding of violence against women is based on the UN definition formulated in 1993: "Violence against women is any act of gender-based violence that results in, or is likely to result in, physical, sexual or psychological harm or suffering for women, including threats of such acts, coercion, or arbitrary deprivation of liberty whether occurring in public or in private life." (1). It is a means taken by the perpetrator to acquire power over other members of a society and subordinate them (2). Several studies and surveys (3-8) revealed that the most common perpetrator is a man and the most common victim is his female partner, so we speak of gender specific violence in partners and intimate relationships. Women often tolerate violence in a partnership, fail to recognise it, find it difficult to resist and even more difficult to leave such a relationship, because they frequently believe that the perpetrator loves them and that he will change (9). They seek reasons for violence in the problems of their partners, they tend to minimise the problem and attribute it to their own behaviour (provoking the partner, refusing sex). Other reasons for staying in a violent relationship include: fear of retribution, lack of an alternative means of economic support, concern for the children, emotional dependence, lack of support from family and friends, and an abiding hope that the man will change (22). By contrast, the public is convinced that violence is not very common, that it occurs only in a certain social stratum, that it is related to addictions, alcoholism, unemployment, poor education and similar reasons. The dynamics of violence, however, are much more complex and a violent relationship cannot be ended easily. Victims perceive and understand reality differently as a result of long-term violence. Violence itself includes complex and sophisticated ways of isolating victims, which influences their physical and mental perception of reality (9). The research into violence in private life and intimate partnerships must be based on the findings of the specifics of life in violent relationships, which is the subject of numerous books and research projects $(8,9,20,25)$.

Recently, violence against women has become an important political issue in Slovenia, which encouraged the passing of the Prevention of Domestic Violence Act (10), which specifies the conduct of public services and requirements for the efficient prevention of violence. Over the past three years, the police and services involved in social care, education and health care had to adopt codes of conduct and affirm their commitment to cooperate. The rules on procedures for dealing with domestic violence in the implementation of health activities were adopted in November 2011 (11). And yet, despite the state's increased interest in this issue, information about violence in Slovenia remained scarce. Researchers relied on foreign studies while attempting to adapt data to local circumstances. However, the international organizations, particularly the UN and WHO, expected Slovenia to devote more attention to data collection as a basis for planning measures and programs. In 2009, this led to a research study entitled "Incidence of violence and responses to it within the private sphere and partnership relations" headed by Dr. Katja Filipčič of the Institute of Criminology with the Faculty of Law in Ljubljana. Part of this study was the first national survey on violence within the private sphere and partnership relations, conducted by Dr. Vesna Leskošek, Dr. Mojca Urek and Dr. Darja Zaviršek (12). The main research question refers to the specificity of Slovene data in relation to the incidence and prevalence of violence. The main hypothesis was that the traditional organisation of gender roles in Slovenia has an impact on women's response to violence. They remain silent and do not report it, which has an impact on their health. In compiling the questionnaire, we leaned on foreign researchers' experience and knowledge $(3-8,13)$. Most of the questionnaires used in these studies were available online, while some were obtained through personal contacts with researchers and the UN Women - United Nations Entity for Gender Equality and the Empowerment of Women, which also provided important guidelines for the research. Due to the limited financial resources, the only possible method of gathering data was a postal survey. Postal surveys have the lowest response rate (28). The reason lies in the dynamics of violence and its impacts. Victims of violence suffer from anxiety and fear and believe that the perpetrators of violence have power to fully control their lives (28). Consequently, they rarely gather the courage to report violence. A larger number of returned questionnaires may be expected in regular surveying performed, e.g. in the United Kingdom annually or biannually in the form of a general questionnaire on personal safety (3).

Key findings show that every second woman (56.6\%) has experienced one of the forms of violence since she turned 15 . They most frequently experienced psychological violence $(49.3 \%)$ followed by physical $(23 \%)$ and property-related violence (14.1\%), limitation of movement (13.9\%) and sexual violence (6.5\%). Every fifth women has experienced violence within the 
previous 12 months, physical (5.9\%), sexual (1.5\%), property-related violence $(7 \%)$ and limitation of freedom (6.1\%).

An important part of the survey was the participants' subjective assessment of their health, the impacts of violence on health and the damage it causes. The impact of violence on health is an important topic in the WHO, which has published several reports on the issue $(6,13,18)$. This article presents the findings of one part of the research concerning the physical and psychological condition of women who suffer violence and the consequences of violence on their health. Because of the space limit, I will not elaborate further on the other results of the survey.

\section{METHODS}

The survey is quantitative and applicative. The objective was to provide an accurate insight into the prevalence of violence, its forms and the resulting damage. The measuring instrument was a survey questionnaire consisting of seven chapters and 68 questions, totally 20 pages long. The main chapters were first demographic data, then personal statuses and circumstances (partnership, citizenship, religious affiliation and health), experience of violence with subthemes of physical, psychological, sexual or economic violence and the restriction of freedom since they turned 15 and in the last 12 months, followed by a chapter on the perpetrators of violence, the decision to break up a violent relationship and the role of services, then the present situation and finally a chapter on social and economic data (housing, employment and income). The questionnaire is available online and easily accessible (the link is in the list of references). Here is a sample of a question on the consequences of sexual abuse:

C14. Have you experienced any of the consequences below within the previous 12 months? (please mark the number in front of the statement, you may choose several options)

1. Physical injuries (state):

2. Sexually transmitted diseases (state):

3. Pregnancy

4. Abortion or miscarriage

5. AIDS

6. Lasting mental distress

7. Other, what

8. I do not know of any consequences

9. I do not have the courage to see the doctor

10.I have not suffered any consequences

11.I have not experienced any sexual violence
We used a representative sample of the general population drawn by the Statistical Office of the Republic of Slovenia in April 2009. The sample consisted of 3000 women aged 18 to 80 , proportionally stratified by age, region and type of settlement.

The response rate was low as expected. 752 or $25 \%$ of questionnaires were returned. The survey took place in May and June 2009. SPSS was used for the statistical analysis. Person's Chi square test was used to test the statistically significant difference.

\section{RESULTS}

In this article, we will concentrate on data concerning mental and physical health. We will compare the data obtained from all the respondents in the sample with those obtained from respondents who experienced physical or sexual violence. The data shows that a quarter of the respondents $(23 \%)$ have experienced physical violence since the age of 15 . Most physical violence against women aged over 15 is perpetrated by men $(92 \%)$. Female perpetrators constitute $8 \%$. A total of $6.5 \%$ of respondents have experienced sexual violence since the age of 15 . Sexual violence is mostly perpetrated by men ( $98 \%)$, with only $2 \%$ being female perpetrators. One of the perpetrators was a female partner in a same-sex relationship.

\subsection{The comparison of the self-assessment of health between all the respondents and those who experienced physical and sexual violence}

More than three fifths $(62.8 \%)$ of all the respondents assessed their health condition as very good or good (Table 1). $6.9 \%$ described their health as poor or very poor. The health condition of women experiencing physical violence is poorer, which is confirmed by the test of statistically significant difference $\left(\mathrm{Hi}^{2}=18.304\right.$; $\mathrm{p}=<0.010) ; 44.6 \%$ of the victims of physical violence assessed their health condition as poor and very poor, compared to $6.9 \%$ in the general population. Sexual violence affects the health condition of women in adulthood, which was also confirmed by the chi-square test establishing statistically significant differences $\left(\mathrm{Hi}^{2}\right.$ $=25.391 ; p=<0.001)$ in the self-assessment of the health condition between the group of women who had experienced sexual violence after 15 years of age and all women. 
Table 1. Self-assessment of health.

Tabela 1. Samoocena zdravja.

\begin{tabular}{|c|c|c|c|}
\hline $\begin{array}{l}\text { Health assessment } \\
\text { Ocena zdravja }\end{array}$ & \begin{tabular}{|l} 
All \\
Vse \\
$(\%)$ \\
$n=752$ \\
\end{tabular} & $\begin{array}{l}\text { Physical } \\
\text { violence } \\
\text { Fizično } \\
\text { nasilje } \\
(\%) n=168 \\
\end{array}$ & $\begin{array}{l}\text { Sexual } \\
\text { violence } \\
\text { Spolno } \\
\text { nasilje } \\
(\%) n=49\end{array}$ \\
\hline $\begin{array}{l}\text { Very good } \\
\text { Zelo dobro }\end{array}$ & 17.8 & 17.3 & 12.4 \\
\hline $\begin{array}{l}\text { Good } \\
\text { Dobro }\end{array}$ & 44.5 & 37.5 & 34.7 \\
\hline $\begin{array}{l}\text { Average } \\
\text { Povprečno }\end{array}$ & 29.6 & 0.6 & 40.8 \\
\hline $\begin{array}{l}\text { Poor } \\
\text { Slabo }\end{array}$ & 6.0 & 35.7 & 8.2 \\
\hline $\begin{array}{l}\text { Very Poor } \\
\text { Zelo slabo }\end{array}$ & 0.9 & 8.9 & 4.1 \\
\hline $\begin{array}{l}\text { Total } \\
\text { Skupaj }\end{array}$ & 98.9 & 100 & 100 \\
\hline $\begin{array}{l}\text { No answer } \\
\text { Ni odgovora }\end{array}$ & 1.1 & & \\
\hline $\begin{array}{l}\text { Total } \\
\text { Skupaj }\end{array}$ & 100 & & \\
\hline
\end{tabular}

\subsection{A Comparison of the self-assessment of health between all the respondents and those who experienced physical and sexual violence}

During the month preceding the survey, $92 \%$ of all the respondents experienced one or more physical or emotional signs of their poor health condition (Table 2). When the values in the "occasionally" and "regularly" categories are combined, it can be observed that the symptoms most often reported by respondents were fatigue (experienced by $52.6 \%$ of all respondents within the previous month) and stress (experienced by $43.1 \%$ of respondents). A third of the respondents suffered from headaches $(33.1 \%)$, followed by anxiety $(24.4 \%)$, insomnia $(23.7 \%)$, indigestion $(22.6 \%)$, constant pain in some part of the body (20.6\%), poor concentration $(20.5 \%)$, fear (18.2\%) and depression and apathy $(17.9 \%) .2 .7 \%$ of the respondents have contemplated suicide within the previous month. $1.5 \%$ of respondents contemplate it regularly.

Statistically significant correlations between the variables of physical and emotional symptoms, and physical violence experienced after the age of 15 are manifested in fatigue $(67.8 \%)\left(\mathrm{Hi}^{2}=30.513 ; \mathrm{p}=<\right.$ $0.000)$, headaches $(42.7 \%)\left(\mathrm{Hi}^{2}=18.977 ; \mathrm{p}=<0.015\right)$, depression $(34.5 \%)\left(\mathrm{Hi}^{2}=41.857 ; \mathrm{p}=<0.000\right)$, anxiety $(34.1 \%)\left(\mathrm{Hi}^{2}=33.982 ; \mathrm{p}=<0.000\right)$, indigestion $(32.7 \%)$ $\left(\mathrm{Hi}^{2}=16.681 ; \mathrm{p}=<0.034\right)$, constant pain in certain bodily parts $(32.2 \%)\left(\mathrm{Hi}^{2}=23.169 ; \mathrm{p}=<0.003\right)$, stomach problems $(31.6 \%)\left(\mathrm{Hi}^{2}=29.842 ; \mathrm{p}=<0.000\right)$, insomnia $(31.6 \%)\left(\mathrm{Hi}^{2}=19.176 ; \mathrm{p}=<0.014\right)$, poor concentration $(30.3 \%)\left(\mathrm{Hi}^{2}=25.148 ; \mathrm{p}=<0.001\right)$, fear $(27.4 \%)\left(\mathrm{Hi}^{2}=\right.$ 34.611; $\mathrm{p}=<0.000)$, vertigo $(21.6 \%)\left(\mathrm{Hi}^{2}=21.898 ; \mathrm{p}\right.$ $=<0.005)$, shaky hands $(16.6 \%)\left(\mathrm{Hi}^{2}=28.097 ; \mathrm{p}=<\right.$ $0.000)$ and suicidal thoughts $(4.8 \%)\left(\mathrm{Hi}^{2}=16.793 ; \mathrm{p}=\right.$ $<0.032$ ). All these symptoms are largely experienced by victims of physical violence.

Statistically significant correlations between the variables of physical and emotional symptoms, and sexual violence experienced after the age of 15 are manifested in depression and apathy (34.7\%) $\left(\mathrm{Hi}^{2}=\right.$ 13.355; $\mathrm{p}=<0.009)$, vertigo $(30.6 \%)\left(\mathrm{Hi}^{2}=18.442 ; \mathrm{p}=\right.$ $<0.001)$, insomnia (30.6\%) $\left(\mathrm{Hi}^{2}=14.457 ; \mathrm{p}=<0.005\right)$, poor concentration $(26.5 \%)\left(\mathrm{Hi}^{2}=10.523 ; \mathrm{p}=<0.032\right)$, memory disorders $(24.5 \%)\left(\mathrm{Hi}^{2}=19.727 ; \mathrm{p}=<0.001\right)$ and shaky hands $(18.3 \%)\left(\mathrm{Hi}^{2}=13.147 ; \mathrm{p}=<0.011\right)$. Women reporting sexual violence significantly more often report constant fear $(32.6 \%)\left(\mathrm{Hi}^{2}=28.097 ; \mathrm{p}=\right.$ $<0.000)$ and constant suicidal thoughts $(14.3 \%)\left(\mathrm{Hi}^{2}=\right.$ 43.389; $p=<0.000$ ). 
Table 2. A comparison of the physical and emotional signs among all the respondents and those who have experienced physical and sexual violence.

Tabela 2. Primerjava telesnih in čustvenih znakov med vsemi respondetkami, doživetim fizičnim in spolnim nasiljem.

\begin{tabular}{|c|c|c|c|c|c|c|}
\hline \multirow[b]{2}{*}{$\begin{array}{l}\text { Physical and emotional signs } \\
\text { Telesni in čustveni znaki }\end{array}$} & \multicolumn{2}{|l|}{\begin{tabular}{|l} 
All \\
Vse \\
$(\%) n=752$ \\
\end{tabular}} & \multicolumn{2}{|c|}{$\begin{array}{l}\text { Physical violence } \\
\text { Fizično nasilje } \\
(\%) n=168 \\
\end{array}$} & \multicolumn{2}{|c|}{$\begin{array}{l}\text { Sexual violence } \\
\text { Spolno nasilje } \\
(\%) n=49\end{array}$} \\
\hline & $\begin{array}{l}\text { Occasionally } \\
\text { Občasno }\end{array}$ & \begin{tabular}{|l} 
Regularly \\
Redno
\end{tabular} & $\begin{array}{l}\text { Occasionally } \\
\text { Občasno }\end{array}$ & \begin{tabular}{|l} 
Regularly \\
Redno
\end{tabular} & $\begin{array}{l}\text { Occasionally } \\
\text { Občasno }\end{array}$ & \begin{tabular}{|l} 
Regularly \\
Redno
\end{tabular} \\
\hline $\begin{array}{l}\text { Stress } \\
\text { Stres }\end{array}$ & 27.1 & 16.0 & 37.5 & 2.0 & 24.5 & 20.4 \\
\hline $\begin{array}{l}\text { Anxiety } \\
\text { Tesnoba }\end{array}$ & 18.0 & 6.4 & 25.6 & 9.5 & 22.4 & 14.3 \\
\hline $\begin{array}{l}\text { Indigestion } \\
\text { Prebavne motnje }\end{array}$ & 14.8 & 7.8 & 20.2 & 12.5 & 2.0 & 8.2 \\
\hline $\begin{array}{l}\text { Loss of appetite } \\
\text { Izguba teka }\end{array}$ & 8.9 & 1.6 & 15.5 & 0.6 & 10.2 & 2.0 \\
\hline $\begin{array}{l}\text { Stomach problems } \\
\text { Želodčne težave }\end{array}$ & 12.2 & 0.9 & 17.3 & 14.3 & 12.2 & 12.2 \\
\hline $\begin{array}{l}\text { Diarrhoea } \\
\text { Driska }\end{array}$ & 7.1 & 2.5 & 7.7 & 4.8 & 8.2 & 4.1 \\
\hline $\begin{array}{l}\text { Headache } \\
\text { Glavobol }\end{array}$ & 23.3 & 9.8 & 30.6 & 12.5 & 24.5 & 14.3 \\
\hline $\begin{array}{l}\text { Constant pain in bodily parts } \\
\text { Stalna bolečina v predelu telesa }\end{array}$ & 10.8 & 9.8 & 15.5 & 16.7 & 4.1 & 2.0 \\
\hline $\begin{array}{l}\text { Weakness in hands and legs } \\
\text { Šibkost v rokah in nogah }\end{array}$ & 9.7 & 5.6 & 10.7 & 7.7 & 14.3 & 8.2 \\
\hline $\begin{array}{l}\text { Fatigue } \\
\text { Utrujenost }\end{array}$ & 30.1 & 22.5 & 32.1 & 35.7 & 26.5 & 28.6 \\
\hline $\begin{array}{l}\text { Heart problems } \\
\text { Težave s srcem }\end{array}$ & 6.5 & 2.9 & 8.3 & 4.2 & 8.2 & 6.1 \\
\hline $\begin{array}{l}\text { Nausea,, vomiting } \\
\text { Slabost in bruhanje }\end{array}$ & 2.4 & 0.8 & 3.6 & 1.8 & 0.0 & 4.1 \\
\hline $\begin{array}{l}\text { Vertigo } \\
\text { Vrtoglavica }\end{array}$ & 9.0 & 3.9 & 15.5 & 6.0 & 20.4 & 10.2 \\
\hline $\begin{array}{l}\text { Shaky hands } \\
\text { Tresenje rok }\end{array}$ & 5.5 & 2.9 & 9.5 & 7.1 & 12.2 & 6.1 \\
\hline $\begin{array}{l}\text { Memory disorders } \\
\text { Motnje spomina }\end{array}$ & 11.6 & 3.7 & 14.3 & 10.1 & 10.2 & 14.3 \\
\hline $\begin{array}{l}\text { Poor concentration } \\
\text { Slaba koncentracija }\end{array}$ & 16.0 & 4.5 & 20.8 & 9.5 & 16.3 & 10.2 \\
\hline $\begin{array}{l}\text { Insomnia } \\
\text { Nespečnost }\end{array}$ & 14.5 & 9.2 & 18.5 & 13.1 & 8.2 & 22.4 \\
\hline $\begin{array}{l}\text { Fear } \\
\text { Strah }\end{array}$ & 12.4 & 5.8 & 16.1 & 11.3 & 12.2 & 20.4 \\
\hline $\begin{array}{l}\text { Depression, apathy } \\
\text { Depresivnost, brezvoljnost }\end{array}$ & 12.5 & 5.7 & 26.2 & 8.3 & 24.5 & 10.2 \\
\hline $\begin{array}{l}\text { Contemplating suicide } \\
\text { Razmišljanje o samomoru }\end{array}$ & 1.2 & 1.5 & 1.8 & 3.0 & 6.1 & 8.2 \\
\hline
\end{tabular}




\subsection{The most common types of physical violence and resulting injuries in the 12 months preceding the survey}

The most common acts of physical violence were (by frequency): pushing, slapping, pulling hair, punching, shoving, arm twisting, kicking, strangling, dragging across the floor, attacks with knives or other weapons ( $1 \%$ of all respondents), banging the head against the wall or other objects, and cigarette burns.

The most common injuries (by frequency) were: bruises, scratches, mental problems, bone fractures, head injuries, concussion, unconsciousness, strained muscles, internal lesions, lasting bodily injuries, wounds, cuts, disability, nose injuries and miscarriages. The respondents also mentioned injuries such as broken teeth, burns, broken veins, poisoning, broken tailbone and broken back. In 2009, $0.4 \%$ of women in Slovenia suffered permanent bodily injuries caused by violence, and $0.3 \%$ remained disabled. $5.5 \%$ of women experienced violence during pregnancy.

It should be emphasised that more respondents answered the question that required the indication of a concrete form of physical violence than the question asking if they had experienced any kind of physical violence. Our assumption is that certain respondents failed to identify certain behaviour as physical violence in the general question but recognised it when it was specifically named and listed.

\subsection{The most common forms and consequences of sexual violence in the 12 months preceding the survey}

The most common forms of sexual violence were unwanted sexual touching that the respondents found distressing and disturbing. This was followed by forced sexual intercourse, rape in partnership, the use of objects against the respondents' will, being prevented from taking contraception and being forced to have an abortion. The strategies of sexual violence therefore include both unwanted pregnancy and the prevention of pregnancy.

The most common consequences of sexual violence are lasting mental distress, physical injuries, miscarriage and unwanted pregnancy. One characteristic of sexual violence is that women report more symptoms of mental distress than physical injuries. Under "other", they listed nightmares, anger, distrust of older men, the feeling of threat, repulsion towards sexual intercourse and bleeding. Some women do not have the courage to see a doctor despite their injuries.

\subsection{Assessment of the damage caused by violence}

In assessing the damage caused by violence, most respondents stated that they could not get rid of their fear $(33.3 \%)$ and did not trust anyone (30.4\%); $23.0 \%$ of the respondents stated that they had psychiatric problems due to violence; $17 \%$ had nightmares and $31.9 \%$ had a physical health condition. Lasting bodily injuries caused by violence were suffered by $8.9 \%$ of women. Personal problems in entering a new relationship were mentioned by $13.3 \%$ of respondents; $3.0 \%$ of women have lost contact with their children because of violence; $2.2 \%$ cannot have children.

A large number of respondents $(6 \%)$ chose the option "Other". Among the damages resulting from violence, they stated depression, occasional anxiety, the loss of self-confidence and a poor self-image, subconscious fear, retreat into isolation, the loss of inner peace, the feeling of guilt and submissiveness. Many women said that they were distrustful of men and more cautious when establishing contacts, and moreover that they had lost contact with old friends, which weakened their personal network. They also had difficulties with establishing sexual relations or felt repulsion towards sexual intercourse.

\subsection{Seeking assistance from the health services}

More than half of the women who have experienced some form of violence remained silent and did not inform anyone rather than seeking help. Those who did report violence most often contacted the police $(36.2 \%)$, social services $(31.3 \%)$, health centres $(22.7 \%)$ and attorneys $(17.2 \%)$. Fewer women talk about violence to priests, call crisis lines or visit a counselling service for women. Under "other," they reported the following services or persons: Human Rights Ombudsman, psychiatric hospital, Society for Non-violent Communication, AlAnon and hospital.

A quarter of women who reported violence had seen a doctor or gone to a hospital due to injuries caused by violence. This corresponds to $6.6 \%$ of women in the general population. Only slightly more than a half of those who see a doctor tell the truth about the origin of their injuries. Most women only admit it after several visits.

\subsection{Alcohol and illegal drug abuse in perpetrators}

According to the assessment of women in the survey that reported on violence, $16.7 \%$ of the perpetrators never consume alcohol to the level of intoxication; 
$20.5 \%$ of perpetrators get drunk a few times a year, $21.2 \%$ a few times a month, $19.2 \%$ a few times a week and $22.4 \%$ every day. $80.8 \%$ of the perpetrators never take illicit drugs, $9 \%$ take them a few times a year, $5.1 \%$ a few times a month, $1.3 \%$ a few times a week and $3.8 \%$ every day.

The regular consumption of alcohol is present in slightly less than a fifth of violence perpetrators. This percentage, however, has to be considered in relation to the drinking culture of Slovenians in general, where a rather high regular consumption of alcohol is demonstrated. The data for 2006 (15) reveals that 12.2 litres of pure alcohol are consumed per adult in Slovenia, which corresponds to $113.1 \mathrm{I}$ of beer, $49.4 \mathrm{I}$ of wine and 2.8 I of spirits. The Slovenian Public Opinion 1999 survey (16) carried out among the inhabitants of Slovenia over 18 , revealed that there were $63.6 \%$ moderate drinkers and $21.4 \%$ excessive drinkers in the adult population of Slovenia. The CINDI survey Health Related Lifestyle 2001 (17) carried out among the inhabitants of Slovenia aged 25 to 64 , revealed that $13.4 \%$ of the respondents $(22.6 \%$ of men and $5.5 \%$ of women) had drunk excessively in the previous 12 months. The results of the CINDI survey in 2008 reveal that the share of men drinking at high risk levels daily is $0.8 \%$ and the share of women $0.1 \%$. The comparison of our data to that gathered by CINDI shows that excessive drinkers are considerably more common in our survey.

\section{DISCUSSION}

The findings of the research show that violence significantly affects women's health, confirming what has already been learned from a number of research studies abroad, scholarly articles and monographs $(2,4-8)$. Lasting violence is a total phenomenon that touches upon and affects all aspects of the victim's life (emotional health, physical health, intimate sphere, financial condition, relations with children and other relatives, social networks, job). Extensive research studies have proved that violence influences physical and sexual health and causes lasting emotional distress, such as depression, self-harmful behaviour, anxiety, outbursts of panic, social phobia, drug addiction and other substance abuse in women (14). The WHO states that violence against women is one of the most serious health problems (18). Such burdens are a consequence of the construction of gender roles in individual cultures and societies. In Slovenia, these find expression in multiple burdens within the private sphere, at work and in women's care role $(20,21)$. The findings of the Institute of Public Health's researchers show that women's mental health is affected by factors such as the worsening of their social and economic situation, discrimination and violence related to women's social status (19). Our research data has confirmed this, given that those women who experienced violence gave a lower self-assessment of their health condition (Table 1). The share of women who experienced physical violence was higher in those reporting fatigue, headaches and depression, more of them suffered from anxiety and insomnia, had poor concentration, and experienced fear and memory disorders. The share of women who experienced sexual violence was higher in those reporting depression, insomnia, poor concentration and memory disorders (Table 2). Similar symptoms are mentioned in the WHO study, which lists anxiety, depression and stress as the most frequent consequences of violence on health (22). Women who experienced physical and sexual violence more frequently cited physical signs of poorer health condition such as a persistent pain in some body part, stomach problems, vertigo and shaky hands. Similar symptoms have been mentioned in other studies on violence against women $(4-8,13)$. An especially high incidence of suicidal thoughts has also been observed, with the highest rate of incidence established among women who experienced sexual violence, and somewhat lower among the victims of physical violence. Studies outside Slovenia have reported similar findings while emphasizing the fact that sexual violence affects the physical and emotional integrity of women so the consequences of this kind of violence are lasting and persistent (23). They can show up even years after experiencing sexual violence.

Various forms of physical violence frequently cause lasting injuries that are revealing of the intensity of the violence. Victims are not only slapped or jostled, but also punched, kicked, pulled by hair or their heads are banged against the wall, with the perpetrators also using various objects such as leather belts, knives and the like. Injuries are physical and psychological. Among the former, let us mention those that cause lasting damages, such as internal lesions, concussion, head injuries, broken bones, teeth and back, and miscarriage. Certain injuries cause permanent disability. In some cases, violence starts during a woman's pregnancy, and in others it starts before and continues throughout pregnancy. With sexual violence, physical injuries are fewer but emotional problems are more numerous. While bleeding, pains, miscarriage or undesired pregnancy are mentioned in this connection, emotional problems such as nightmares, fear and anxiety, or 
undesired emotions such as anger, distrust, the feeling of threat and repulsion towards sexuality are much more common.

Regardless of the type of violence, women report that they cannot get rid of fear even when they are no longer exposed to violence. They have difficulties establishing trustful relationships. Emotional problems are persistent and affect their everyday lives, which is the reason why we define violence as a total phenomenon. The consequences are also reflected in the victims' economic situation, social networks, relations at work and other areas.

Furthermore, distrust, shame and fear affect women's attitude towards various public services. Few women are willing to speak about violence. Less than one third of our respondents confided in health centre staff, while some talked about their experience to the staff in a psychiatric or general hospital. One fourth of women who experienced violence visited a doctor or ended up in a hospital due to injuries, and only half of them admitted the real source of the injury, which indicates the complexity of violence dynamics. Therefore, when dealing with women it is necessary to be able to recognize injuries and signs of violence so that the victim can be encouraged to report it. However, people dealing with the victims of violence need to have special knowledge to avoid causing additional problems that could be experienced as secondary victimization. A trustful relationship between professional worker and victim is of essential importance (29). Victims usually only confide in a doctor after several visits, when such a relation is established and the victim feels safe. At any rate, trust is one of the most important attributes of the professional-patient relationship (24).

We should also mention the frequently mistaken interpretation of data on alcohol use. Research studies on violence against women have found higher percentages of individuals who regularly drink to intoxication regardless of the quantity of alcohol consumed. However, it has also been established that a high percentage of perpetrators never consume alcohol or consume it only a few times a year; in our research, women respondents assessed that they account for slightly more than one third of the perpetrators. Social sciences address the issue of violence against women and children within the framework of the power paradigm. The more a society is patriarchal, the greater the possibility that men will see the power as residing with them in both the private and public spheres. Women submit to them in order to meet the demands of the social gender order. Violence had been acceptable for quite a long time, because it had been understood as part of masculinity, while women had to endure violence and repeatedly find ways to avoid or manage it. Exploiting the power of violence to subordinate and deprive one of dignity and respect is still a convenient way of establishing hierarchical relations, the more powerful vs. the weaker, in most cases men vs. women and children (25). Alcohol can therefore be one of the many causes of violence, although the same man can also perpetuate violence when not intoxicated. The dynamics of violence is such that its frequency increases, meaning that the interval between individual instances of violence decreases regardless of the state of the perpetrator or the victim's behaviour. Alcohol is therefore understood as a risk factor rather than the cause of violence, since there is no direct correlation between alcohol and violence (26). On the contrary, many men are not violent when intoxicated (27).

\section{CONCLUSIONS}

In the opinion of the Institute of Public Health's researchers, violence in Slovenia has not been recognized as an important problem in public health. Consequently, insufficient attention has been devoted to prevention, with the identification of victims in health care being poor and measures undertaken ineffective (20). An important step forward was the adoption of the Rules on procedures for dealing with domestic violence in the implementation of health activities (12), which sets the professional and ethical standards for dealing with the victims of violence. The document imposes the obligation on health care workers to report violence, to cooperate within multi-disciplinary teams at centres for social work, and to assess the threat to the victim. The document further specifies that health workers should acquire relevant knowledge and skills through additional training programs. While it is an important step in dealing with violence within health care, there are also other measures pointed out by the WHO that should be implemented. Violence against women is also a public health problem because of the high expenses of treating injuries caused by violence. Female victims of violence seek a doctor's help, receive hospital treatment and need medicines more often than women who have no such experience (22).

The starting point for the WHO's recommendations for public health services is the fact that it is the public health institutions that come into contact with almost all victims of violence, so their staff needs to be highly trained to recognize violence and handle it effectively. Accordingly, they should establish cooperation with 
other institutions trained to handle violence, which will enable them to avoid the excessive burden that could reduce the likelihood of dealing effectively with the problem. It is important to sensitize health care providers and encourage routine screening for abuse, as well as to draw up protocols for the proper management of abuse. Confronting deep-rooted beliefs and attitudes is also important. Research suggests that making procedural changes in patient care - such as stamping a reminder for the provider on the patient's chart or incorporating questions on abuse into the standard intake forms - have the greatest effect on the behaviour of health care providers (22).

Given these recommendations, the above-mentioned rules should be complemented with implementation documents. Moreover, conduct protocols within individual institutions should be drawn up and responsibilities clearly defined; professional doctrines should be developed and all health care workers who are obliged to take measures should be adequately trained.

\section{References}

1. Declaration on the elimination of violence against women. United Nations, General Essembly, A/RES, 1993.

2. Kelly L. Violence against women and children: vision, innovation and professionalism in policing. Strasbourg: Council of Europe Publishing, 2003.

3. British crime survey. London: Home Office, 1999, 2001, 2005.

4. Ollus $\mathrm{N}$, Johnson $\mathrm{H}$, del Frate AA, Nevala S. International violence against women survey: manual and questionnaire. HEUNI, United Nations Office on Drugs and Crime, UNICRI and Statistics Canada, 2003.

5. Piispa M, Heiskanen M, Kääriäien J, Sirén R. Violence against women in Finland: research report. Helsinki: National Research Institute for Legal Policy, The European Insitute for Crime Prevention and Control affiliated to United Nations, 2006.

6. Ellsberg M, Heise L. Researching violence against women: a practical guide for researchers and activists. Washington DC: WHO and PATH, 2005.

7. Lundgren E, Heimer G, Westersrand J, Kalliokoski AM. Captured queen: men's violence against women in »equal« Sweden: a prevalence study and a questionnaire. Brottsoffermyndigheten, Umea and Uppsala University, 2001.

8. Watson D, Parsons S. Domestic abuse of women and men in Ireland: report on the national study on domestic abuse and questionnaire. Dublin: Stationery Office, 2005.

9. Rommelspacher B. Ali je ženski mazohizem mit? In: Zaviršek D, editor. Spolno nasilje: feministične raziskave za socialno delo. Ljubljana: Visoka šola za socialno delo 1996: 5-32.

10. Zakon o preprečevanju nasilja v družini. Ur. L. RS 2008; 16.

11. Pravilnik o pravilih in postopkih pri obravnavanju nasilja v družini pri izvajanju zdravstvene dejavnosti. Ur. L. RS 2011; 38.

12. Leskošek $\mathrm{V}$, Urek M, Zaviršek D. Nacionalna raziskava o nasilju $v$ zasebni sferi in partnerskih odnosih: končno poročilo 1. faze raziskovalnega projekta. Ljubljana: Inštitut za kriminologijo pri Pravni fakulteti, 2010. Pridobljeno 25. 8. 2010 s spletne strani: http://www.arhiv.uem.gov.si/fileadmin/uem.gov.si/pageuploads/ NasiljeRaziskava2010.pdf

13. WHO multi-country study on women's health and domestic violence against women: initial results on prevalence, health outcomes and women's responses. Geneva: World Health Organisation, 2005.

14. Department of Health. Women's mental health: into the mainstream: strategic development of mental health care for women, 2002. Pridobljeno 25. 8. 2010 s spletne strani: http:// www.dh.gov.uk

15. Kovše K, Nadrag P. Poraba alkohola in kazalci škodljive rabe alkohola v Sloveniji leta 2006. Ljubljana: Inštitut za varovanje zdravja, 2008. Pridobljeno 29. 7. 2012. s spletne strani: http://ivz. arhiv.over.net/javne_datoteke/datoteke/1737Raba_alkohola_v_ letu_2006.pdf

16. Slovensko javno mnenje 1999; 3.

17. The CINDI survey health related lifestyle 2001: epidemiologic surveys on drinking behaviour in Slovenia. Pridobljeno 29. 7. 2012 s spletne strani: http://www.ivz.si/ Mp.aspx?ni=12\&pi=5\&_5_id=565\&_5_Pagelndex=0\&_5_ groupld=180\&_5_newsCategory=\&_5_action=ShowNewsFu $\|$ I\&pl=12-5.0.

18. Violence against women. Intimate partner and sexual violence against women. Fact sheet 239, 2011. Pridobljeno 3. 9. 2012 s spletne strani: http://www.who.int/mediacentre/factsheets/ fs239/en/index.html

19. Mihevc-Ponikvar B, et al. Zdravje žensk med 20. in 24. letom. Ljubljana: Inštitut za varovanje zdravja, 2010.

20. Humer Ž. Skrbstvene aktivnosti moških v družinskem življenju. Družboslovne razprave 2007; 23: 75-90.

21. Kamin T, Berzelak N, Ule M. The influence of education on differences in depressive symptoms between men and women in Slovenia. Zdrav Var 2012; 51: 33-42.

22. Krug EG et al., editors. World report on violence and health. Geneva: WHO, 2002. Pridobljeno 3. 9. 2012 s spletne strani: http://whqlibdoc.who.int/publications/2002/9241545615_eng.pdf

23. Pico-Alfonso MA et al. The impact of physical, psychological and sexual intimate male partner violence on women's mental health: depressive symptoms, posttraumatic stress disorder, state anxiety and suicide. J Women Health 2006; 15: 599-611.

24. Mencin-Čeplak M, Hlebec V. Trust in individual physician and its contradictions. Zdrav Var 2012; 51: 53-68.

25. Kelly L. Spolno nasilje in feministična teorija. In. Zaviršek D. Zaviršek $D$, editor. Spolno nasilje: feministične raziskave za socialno delo. Ljubljana: Visoka šola za socialno delo, 1996: 69-98.

26. Chan C. Alcohol issues in domestic violence: topic paper. Australian Domestic and Family Violence Clearinghouse. Pridobljeno 3. 9. 2012 s spletne strani: http://www.adfvc.unsw. edu.au/PDF\%20files/Alcohol_Issues.pdf

27. Galvani S. Alcohol and domestic violence: women's views. Violence against Women 2006; 12: 641-662.

28. Walby S. Improving the statistics on violence against women: expert paper. Geneva, UN Division for the Advancement of Women in collaboration with Economic Commission of Europe and World Health Organisation. Expert group meeting, 2005.

29. Pahor M, Domanjko B, Hlebec V. Social support in the case of illness: intergenerational solidarity. Zdrav Vestn 2011; 80: 75-83. 